\title{
Chapter 17 \\ Prehistoric Human Tracks in Ojo Guareña Cave System (Burgos, Spain): The Sala and Galerías de las Huellas
}

\author{
Ana I. Ortega, Francisco Ruiz, Miguel A. Martín, Alfonso Benito-Calvo, \\ Marco Vidal, Lucía Bermejo, and Theodoros Karampaglidis
}

\begin{abstract}
In 1969, members of Grupo Espeleológico Edelweiss discovered the Sala and Galerías de las Huellas in Ojo Guareña Cave system (Burgos, Spain). These contained hundreds of ancient human footprints, preserved in the soft sediment on the floor. These footprints represent the tracks of a small group of people who walked barefoot through these complex passages in the cave. Owing to the difficult compatibility of the documentation and preservation of these prints, it was not possible to study them before the development of new non-invasive remote sensing techniques. However, since 2012 optical laser scanning and digital photogrammetry have been used in Galerías de las Huellas, in combination with GIS techniques, to obtain a model of the cave floor, where the footprints and their internal morphology can be observed in detail. We have identified over 1000 prehistoric human footprints and at least 18 distinct trackways through the passages, which could have been left by around 8-10 individuals. Since 2016, an archaeological field study has been conducted in this sector, in order to determine and explore its surrounding area and find other archaeological evidence that may be directly associated with these tracks. Numerous remains of torches are preserved on the walls and floor in the immediate surroundings of the footprint sites. Some of them have been dated, which has
\end{abstract}

\footnotetext{
A. I. Ortega $(\triangle)$

Centro Nacional de Investigación sobre la Evolución Humana - CENIEH, Burgos, Spain

Fundación Atapuerca, Burgos, Spain

Grupo Espeleológico Edelweiss, Burgos, Spain

e-mail: anaisabel.ortega60@gmail.com

F. Ruiz · M. A. Martín

Grupo Espeleológico Edelweiss, Burgos, Spain
}

A. Benito-Calvo $\cdot$ M. Vidal · T. Karampaglidis

Centro Nacional de Investigación sobre la Evolución Humana - CENIEH, Burgos, Spain

Grupo Espeleológico Edelweiss, Burgos, Spain

L. Bermejo

Centro Nacional de Investigación sobre la Evolución Humana - CENIEH, Burgos, Spain

(C) The Author(s) 2021

A. Pastoors, T. Lenssen-Erz (eds.), Reading Prehistoric Human Tracks, https://doi.org/10.1007/978-3-030-60406-6_17 
revealed the intensive use of this underground landscape from the Upper Palaeolithic to the Mesolithic-Neolithic. However, the remains in Sala and Galerías de las Huellas date solely to the Chalcolithic, around 4300 calBP.

Keywords Human footprints - 3D laser scanner - Ojo Guareña Cave system · Exploration $\cdot{ }^{14} \mathrm{C}$ data $\cdot$ Chalcolithic

\section{Introduction}

The Ojo Guareña Cave system, forming one of the most important underground systems in Spain, is located in the Cantabrian Mountains and the Upper Ebro Basin, in the north of the Province of Burgos (Spain) (Fig. 17.1a). This cave system developed in the northern flank of the Mesa-Pereda syncline (del Olmo et al. 1978), in the Coniacian (Late Cretaceous) limestone and dolomite unit. Ojo Guareña is an extensive multilevel cave system, formed by the connection of 14 caves and over $110 \mathrm{~km}$ of passages, distributed on 6 main interlinked levels, from a relative height of $+70 \mathrm{~m}$ to the current level of the River Guareña (Grupo Espeleológico Edelweiss 1986; Ortega et al. 2013: 45-53).

The blind valley of San Bernabé ends at the Guareña sinkhole and contains a series of old fossil entrances perched at different heights above the River Guareña (at $692 \mathrm{~m}$ a.s.l.) that, together with the River Trema (karst discharge zone) and the Villamartín stream, has shaped this singular karst landscape listed as Natural and Cultural Heritage of Spain.

This karst complex contains an impressive record of human activities from at least the Upper Pleistocene. The archaeological sites were discovered at the same time as speleological explorations were taking place. The diversity and variety of archaeological remains, in more than 80 sites (Ortega and Martín 1986; Ortega et al. 2013: 164-236), include living areas in cave entrances, rock art, burials, human bones, grave goods or different archaeological objects, which demonstrate the use of this cave landscape from the Middle Palaeolithic to the Middle Ages.

The hundreds of human footprints in the soft sediment on the floor of Sala and Galerías de las Huellas I and II are among the most singular and vulnerable archaeological sites in the cave system. They were found in 1969 by members of the Grupo Espeleológico Edelweiss, during the survey of one of the most labyrinthine sectors of the system, called Dédalo Oeste (Uribarri 1969; Osaba 1969: 305-309; Rubio 2001), which is related to the geomorphologic evolution of the Guareña blind valley and San Bernabé cirque. 

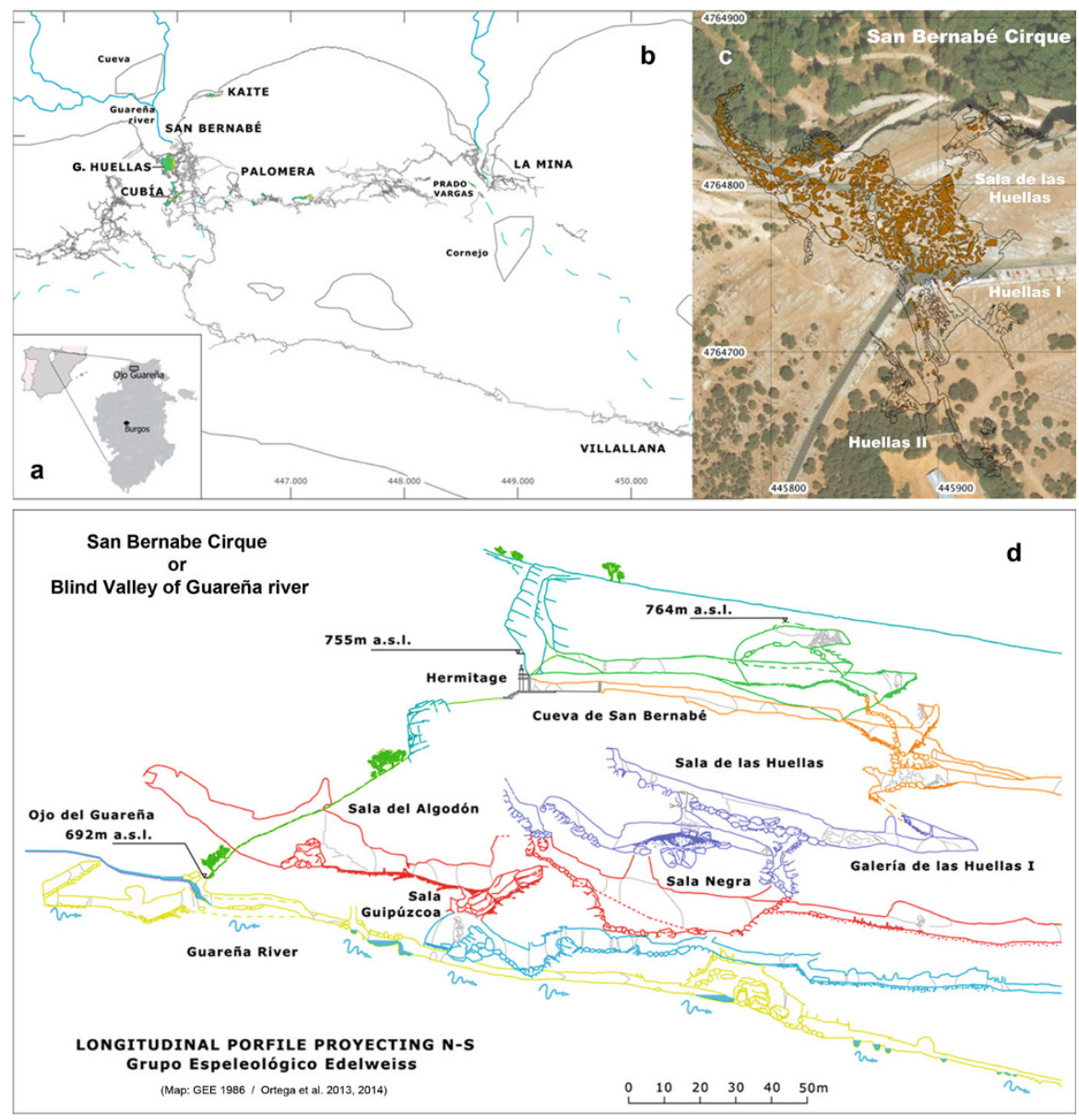

Fig. 17.1 (a) Situation of the Ojo Guareña karst in the Iberian Peninsula; (b) location of the Sala and Galería de las Huellas sites in the Ojo Guareña complex, with reference to the main caves; (c) map of Sala and Galería de las Huellas with an orthophoto of the PNOA (IGN, Spain); (d) longitudinal profile, projection N-S, of the Ojo Guareña Cave system in the blind valley of the Guareña River. (Modified from Grupo Espeleológico Edelweiss 1986; Ortega et al. 2013, 2014)

\section{The Site}

The Sala and Galerías de las Huellas formed in the third karst level known as Dédalo Oeste. It covers an area of $5652 \mathrm{~m}^{2}$ and connects with Laberinto Otilio and Sala Negra in the fourth level. This third level is perched at $40 \mathrm{~m}$ above the Guareña River level and comes very close to San Tirso and Bernabé Cave, whose passages belong to the second karst level (Fig. 17.1c). Their western passages descend until they link topographically with the end of Galería de las Huellas I (GH I), although without a physical connection because of the collapse of the cave ceiling and the growth of a 
large speleothem (Grupo Espeleológico Edelweiss 1986, Annex mapping 153-3; Martín 1986: 141-147; Ortega and Martín 1986: 342-343). Additionally, sediment on the San Bernabé hillsides has completely silted up the old entrances in this sector, so current access is from Palomera Cave, $1250 \mathrm{~m}$ to the west.

Sala de las Huellas is an enormous chamber $80 \mathrm{~m}$ long, $50 \mathrm{~m}$ wide and more than $5 \mathrm{~m}$ high, with large boulders that have collapsed from the ceiling and obstruct transit (Figs. 17.1 and 17.2f). Galerías de las Huellas I and II (GH I and GH II) are located on the south side of this chamber (Figs. 17.1b, 17.2c, $g$ and 17.9a). The first gallery (GH I) consists of a main passage, 60-m-long and a 25-m-long side passage (Figs. 17.2g and 17.3d). The main axis of the second gallery (GH II) is approximately $100 \mathrm{~m}$ long. Both galleries are about $5 \mathrm{~m}$ wide and $4-5 \mathrm{~m}$ high (Fig. 17.3f, g).

The floor of these galleries is characterized by interior cave sediments, with a loamy texture and composition mainly of calcite, quartz, feldspar and to a lesser extent phyllosilicates (Benito-Calvo et al. 2013: 220).

Small channels have incised the floors of both galleries, particularly in the final section of GH II. The entry sections have calcite crusts, which do not register any footprints. On the contrary, the deposition of fine calcite crystals makes it difficult to recognize many of the impressions, especially in the GH I gallery.

The human traces located in these passages are very well preserved in both galleries, thanks to the protection measures that were taken at the time of the discovery, limiting access to the sites and waymarking alternative routes (Fig. 17.3). But unfortunately the difficulty of transit in the large chamber (Sala de las Huellas) led to the destruction of many traces, and only a few footprints have been preserved on large boulders (Figs. 17.2f and 17.3a).

The cave survey in this sector was finished in 1970, and Almagro invited André Leroi-Gourhan to plan a project to study the footprints, including photogrammetric analysis. Unfortunately, it never materialized. Plaster casts of two footprints were made at that time, and a sediment sample from the first passage was sent to León Pales and Michel-Alain García (Ortega et al. 2013: 178-182; 2014: 43-44). In addition, charred wood remains were collected from Laberinto Otilio in the lower level, at the bottom of a shaft from GH I, and interpreted as thrown or fallen from that gallery. They were dated to $15,600 \pm 230 \mathrm{BP}$ (Delibrias et al. 1974: 53).

New surveying in 1981 (Grupo Espeleológico Edelweiss 1986) achieved an acoustic connection between GH I and the southwestern passage in San Bernabé Cave (Fig. 17.1b). This connection motivated the dating of the speleothem plug that separates the two caves. Rainer Grün, who was visiting Spain to sample caves for his $\mathrm{PhD}$, dated the speleothem to about $175 \mathrm{ka}$ (pers. comm. Adolfo Eraso). This age prompted a new study of the footprints and their superpositions, in order to determine the direction of the prints through photographic and photogrammetric analysis (Galaz et al. 2000). These studies showed that the prints followed an entry and exit route within Sala de las Huellas (Galaz et al. 2000; Ortega et al. 2013: 178-182) and that they were, therefore, not connected with the passage in San Bernabé Cave.

This new study also identified traces of small carnivores (mustelid-type) especially in the eastern gallery (GH I), in whose initial section bear claw scratches are also preserved on the walls. Some charred wood remains have also been observed on 

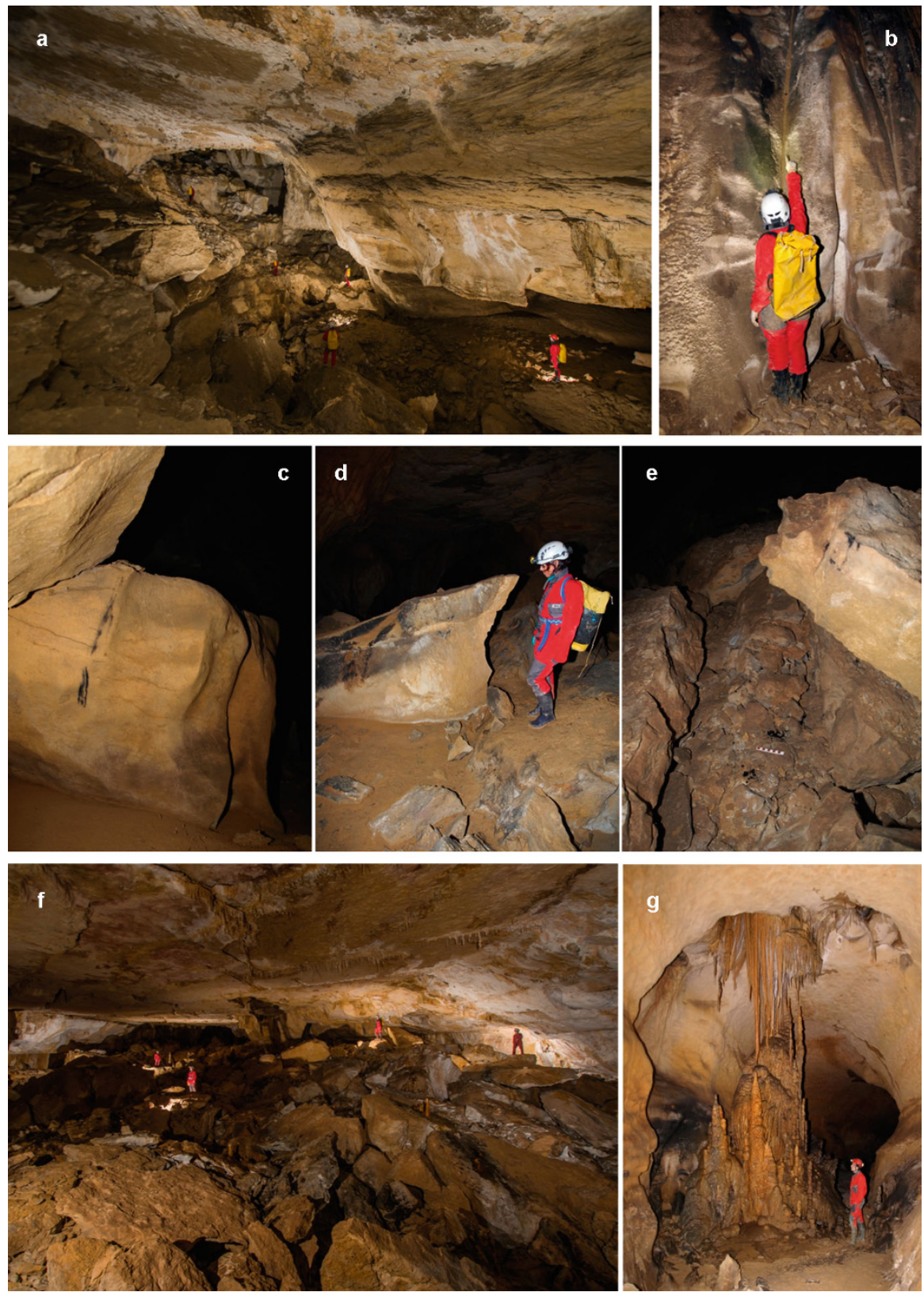

Fig. 17.2 (a) General overview of the Sala Negra; (b) charcoal samples (No 11 and 12) located in the connection shaft between Galería de las Huellas I and Laberinto Otilio; (c) charcoals in the block (No 10) of Laberinto Otilio; (d) block decorated with torch remains and charcoals in the ground (No 14, Laberinto Otilio); (e) torch remains on a block, with charcoals in the floor (No 4), of the Sala de las Huellas; (f) general view of Sala de las Huellas; (g) cross section view of the beginning of Galería de las Huellas II. (Photos (a) P. Carazo-Grupo Espeleológico Edelweiss; (b-f) M.A. Martín -Grupo Espeleológico Edelweiss) 

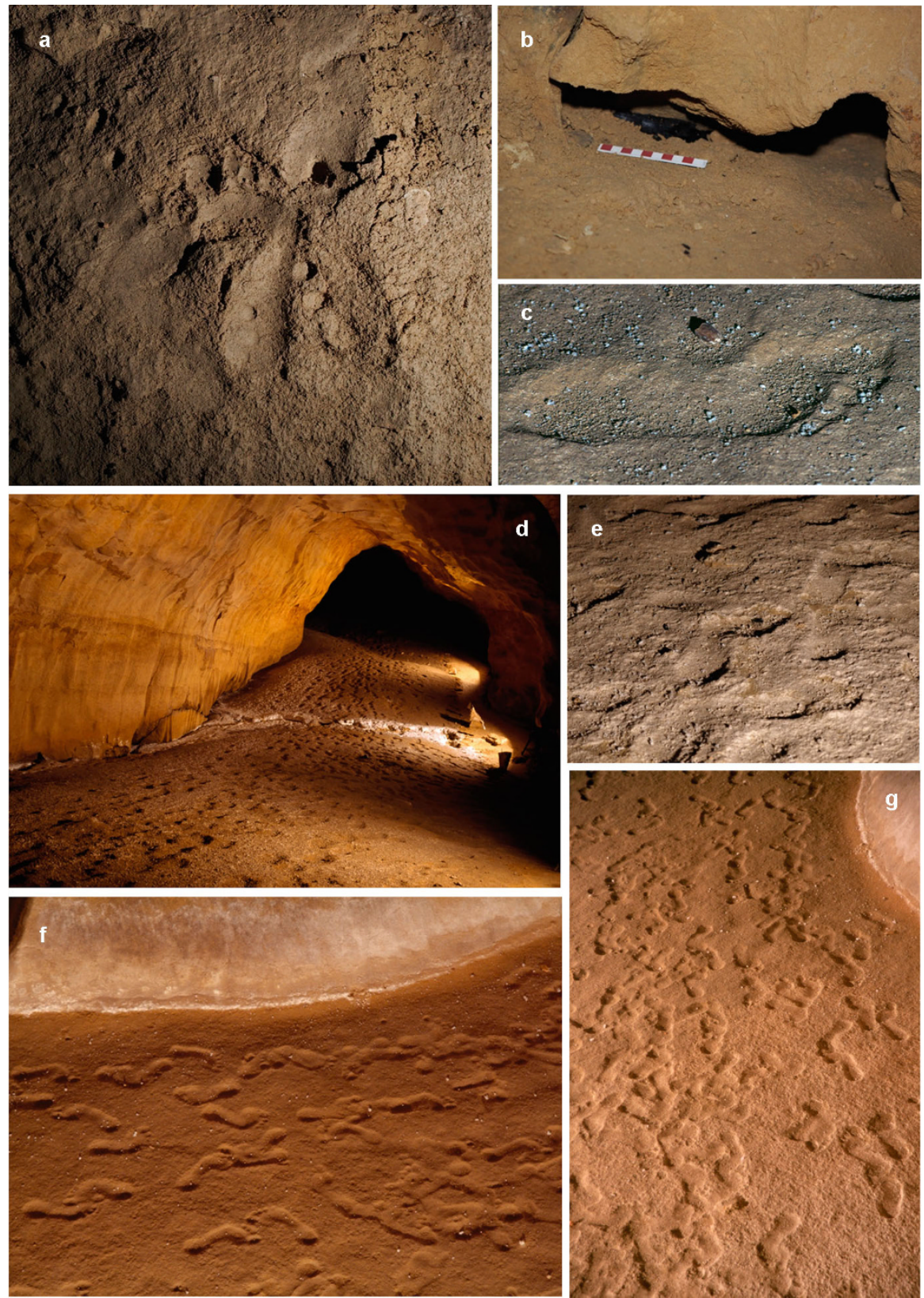

Fig. 17.3 (a) Human footprints on a large block of the Sala de las Huellas; (b) remains of a torch under a block of Sala de las Huellas (No 1); (c) detail of a footprint of Galería de las Huellas II; (d) view of Galería de las Huellas I; (e-g) several views of the traces of the Galería de las Huellas II. (Photos M.A. Martín-Grupo Espeleológico Edelweiss) 
the walls and floors of Galerías de las Huellas, although charcoal remains are more numerous in the lower passages (Laberinto Otilio and Sala Negra). In 1999, a charcoal sample from the western Galería de Las Huellas (GH II) provided a date of $3820 \pm 50 \mathrm{BP}$ (pers. comm. Juan Luis Arsuaga). This date was very different from the Palaeolithic date mentioned above and showed that the passages had been entered again in recent prehistory.

\section{Access to a Complicated Sector}

It was traditionally thought that the access to Galerías de las Huellas during prehistory was from the blind valley of the Guareña River or the San Bernabé cirque, given its obvious proximity (Ortega and Martín 1986: 342-343). Later, the possibility of access from San Bernabé Cave was discarded, because of the age of the collapse now blocking the cave, which is sealed by a thick speleothem (Ortega et al. 2013, 2014). Finally, direct access from outside to the Sala Negra has also been discarded, given that the current blockage of boulders, a consequence of the receding hillside, seems very stable and was already consolidated in the Neolithic, according to the dates obtained in the framework of this project (Table 17.3) (Ortega and Martín 2019).

In contrast, recent investigations into the archaeological evidence inside Palomera Cave, currently the main entrance to the Ojo Guareña Cave system, indicate that transit inside this large cave was much more frequent and intense than previously thought. This is evidenced by the succession of archaeological remains that extend up to almost a kilometre and a half from the current entrance, towards both the east and the west, belonging to different periods from prehistory to the Middle Ages.

On the route from Palomera Cave to the surroundings of Las Huellas (Fig. 17.4), several archaeological remains have been documented in the passages of Museo de Cera, Galería de la Escalada and Galería Macarroni, with confirmed prehistoric dates. The distance from the start of the latter gallery to the Sala del Cacique is barely $100 \mathrm{~m}$; it is very comfortable to walk through and currently included in the tourist route. It is a further $100 \mathrm{~m}$ from this point to the first side passage in Galería del Cacique, which leads to Laberinto Otilio. This is the beginning of the sector studied here, where abundant charred wood marks on the walls and pieces of charcoal on the loamy floor and boulders have been identified.

There are several points of access to the Sala and Galerías de las Huellas in this area. One of them starts at the northeast end of Sala Negra, which finishes in an impressive boulder blockage (Figs. 17.2a and 17.9b), where the presence of charcoal confirms the transit, at least in the Early Neolithic (Fig. 17.9b, number 13 and Table 17.3). Another access point, which is a little more comfortable, is through a side passage that ascends gently towards Laberinto Otilio until Sala de las Huellas can be reached by climbing between boulders. As already stated, the entire route is full of charred wood marks and pieces of charcoal (Figs. 17.2b-g and 17.9). 
A. I. Ortega et al.

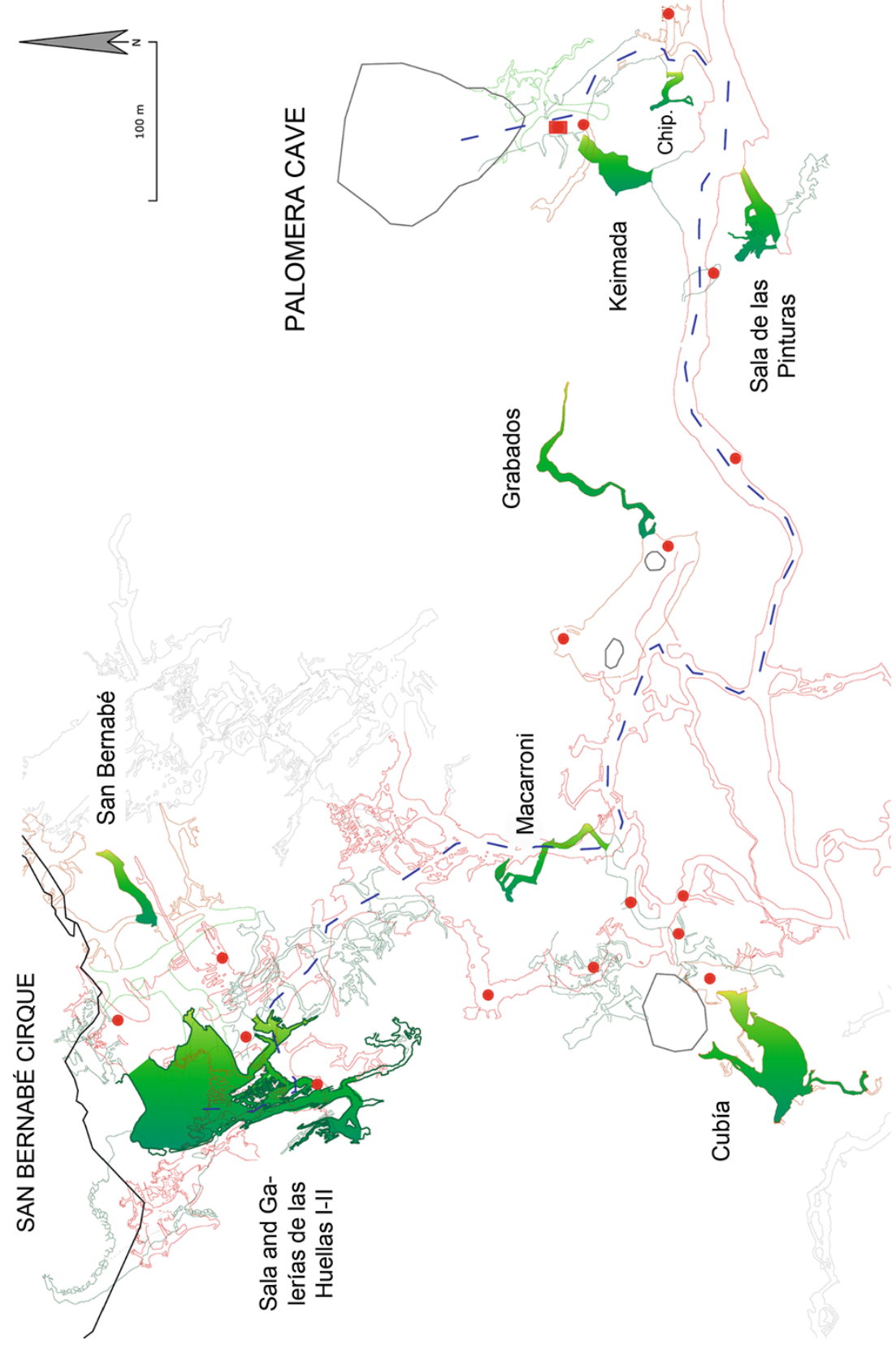

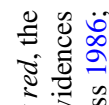

굴

政

J 8

o

ฮิ

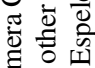

응응

능 훙

远

의

灵完

正这

ن

क

巳

क

곯

요

๘

के

䓀

๑ :

를

क 0

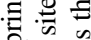

응

$\because \stackrel{0}{0}$

สี 을

至

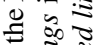

०ᄋ: इ

원

$0 \div$

की $\frac{3}{2} \sqrt{2}$

ठ্ঠ

竞导

نं

일

둥

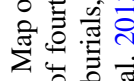

त. के

今.

홍 
This evidence suggests that, after a 1200-m-long route of easy transit through large underground passages, prehistoric humans explored a sector of Palomera Cave that is more complex because of its large size $\left(5652 \mathrm{~m}^{2}\right)$, intricate topography (mazes) and instability (with large embedded boulders that hinder transit). Despite this danger, at least one of the human groups that walked through this sector could have reached the upper level of the Sala and Galerías de las Huellas.

\section{Materials and Methods}

\section{Footprint Documentation}

Human footprint sites are not very common in the archaeological record because of the special requirements for their formation and preservation, although the number of cases has increased over time (Lockley et al. 2008; Bennett and Morse 2014a). These footprints provide information on human behaviour regarding the environment and on the nature of the sediments, where fine-grained substrates favour the formation and preservation of the prints (Bennett and Morse 2014b). The difficulty in balancing the documentation and conservation of these traces has conditioned their study for many years, and it only became possible with the development of non-invasive digital remote sensing technologies applied to archaeological research and heritage management (Bennett et al. 2013; Ashton et al. 2014; D. Webb et al. 2014; Citton et al. 2017).

The study of the human footprints in Ojo Guareña started in 2012. It focused on accurate three-dimensional reconstruction of Galería de las Huellas I and II, using 3D laser scanner technology and GIS methodologies (Benito-Calvo et al. 2013; Ortega et al. 2014). Sala de las Huellas was excluded from this work because of its topographic irregularity and the difficulty of transit in such a chaotic space.

The three-dimensional mapping of this site was achieved with a ScanStation C10 Leica laser scanner, with a maximum flight range of $300 \mathrm{~m}, 4 \mathrm{~mm}$ accuracy. Seventeen high-resolution scans were performed $(5 \mathrm{~mm}$ at $10 \mathrm{~m})$, seven in $\mathrm{GH} \mathrm{I}$ and ten in GH II. The point clouds obtained were joined by a common reference system with reference targets, obtaining a mean error of $1 \mathrm{~mm}$, with final point clouds that reached resolution means of $3 \mathrm{~mm}$ in GH I and $4 \mathrm{~mm}$ in GH II.

The models of the obtained surfaces were exported to GIS format, generating high-resolution digital elevation models (DEM) that show the topographic relief of the galleries with sufficient resolution to analyse the shape and distribution of the tracks (Benito-Calvo et al. 2013). The terrain roughness index (TRI) model (Riley et al. 1999) allows the irregularities of the floor to be differentiated (white colours) from the softer areas (black colours) by stressing the depressions of the best preserved footprints according to their internal morphology (sole, heel, toes, etc.). 


\section{Footprints and Trackways}

This precise cartography allows the position of the tracks to be observed in relation to the morphology of the passages by identifying not only the human footprints but also the topographic elements (boulders, rocks, speleothems, crusts, channels, etc.) that form the surface and condition the presence of human footprints. This enables the reconstruction of some of the paths and movements made by these ancient visitors. All the measurements and most of the observations of the footprints have been made over the resulting three-dimensional and cartographic restitution with AutoCAD software, as it is not possible to measure them in situ, owing to the nonconsolidation of the sediment recording the traces.

Once the footprints were scanned, each of the prints was individualized.

The maximum length (FL) was measured parallel to the longitudinal axis of the footprint, while the width of the ball (FW) and the width of the heel (FHW) were measured perpendicular to the FL axis. The longitudinal axis was determined following the technique of D. Webb et al. (2006a).

From the FL and FW measurements, the footprint index (FI) was calculated, which consists of the ratio between foot width and foot length: FI $=$ FW/FL $\times 100$.

The arch index (AI) is a widely used measurement for the purpose of classifying the foot type according to a high (AI $\leq 0.21)$, normal $(\mathrm{AI}=0.21-0.26)$ and flat (AI >0.26) arch (Cavanagh and Rodgers 1987). AI was measured according to Cavanagh and Rodgers (1987), whereby a perpendicular line to the foot axis was used to divide the toeless area into equal thirds (Fig. 17.5a): rearfoot (A), midfoot (B) and forefoot $(\mathrm{C})$ regions. Then, AI was calculated as the ratio of the area of the midfoot to entire toeless footprint area: $\mathrm{AI}=\mathrm{B} /(\mathrm{A}+\mathrm{B}+\mathrm{C})$.

Finally, arch angle (AA) or Clarke angle is defined as the angle between the medial border line of the footprint and the line connecting the most medial point of the metatarsal region of the footprint and the apex of the concavity of the arch of the footprint (Citton et al. 2017) (Fig. 17.5a). AA is a conventional measurement that classifies the internal longitudinal arch between tendency to flatness or pronation $\left(\mathrm{AA} \leq 31^{\circ}\right)$, normality range $\left(\mathrm{AA}=31^{\circ}-45^{\circ}\right)$ and tendency to cavus foot $\left(\mathrm{AA}>45^{\circ}\right)$ (González-Martín et al. 2017).

\section{Estimation of Height and Weight}

Many studies support the use of foot length to obtain an individual's range of height, while body mass can be estimated by the correlation between foot width and body weight (D. Webb et al. 2006a; Ukoha et al. 2013; Atamtürk and Duyar 2008; Krishan 2008; Robbins 1986). 


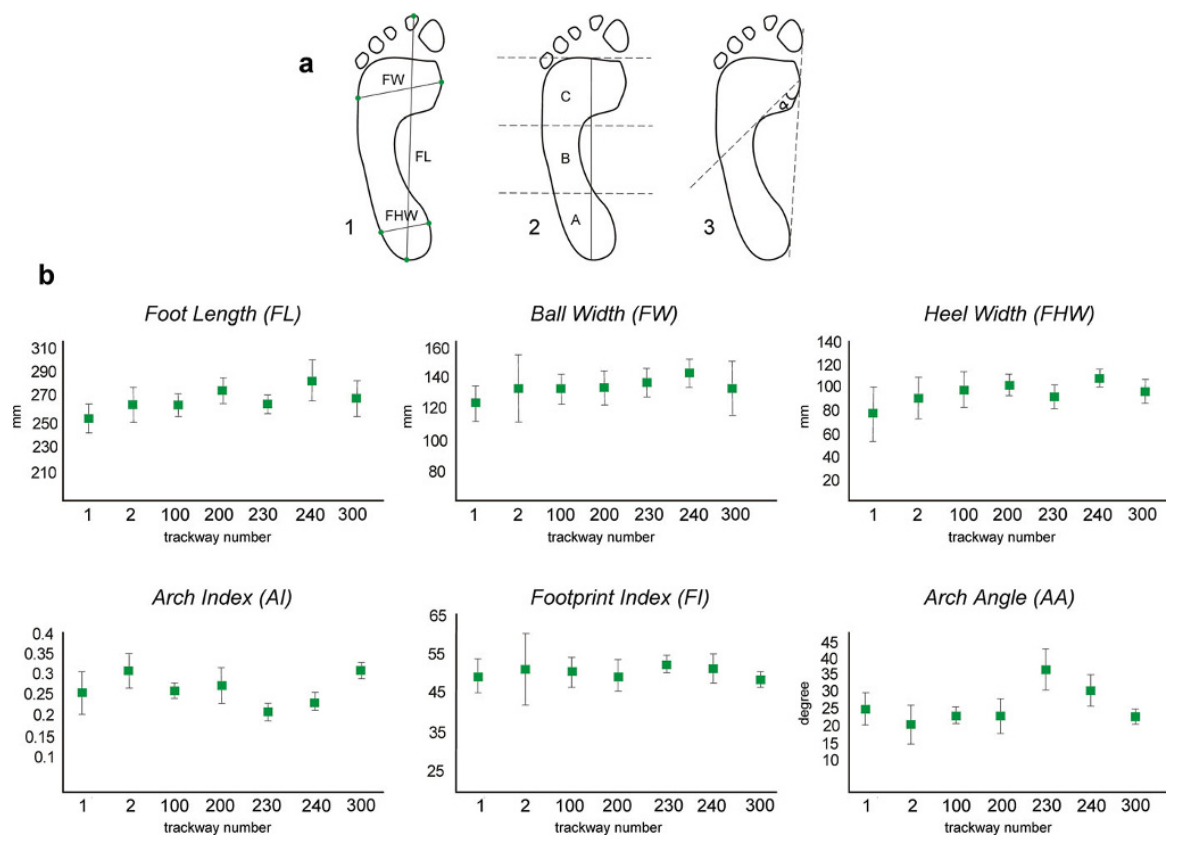

Fig. 17.5 (a) Morphological parameters used in the current study, (1) maximum foot length (FL), width of the ball $(\mathrm{FW})$ and width of the heel $(\mathrm{FHW}),(\mathbf{2})$ arch index $(\mathrm{AI}=\mathrm{B} / \mathrm{A}+\mathrm{B}+\mathrm{C}),(\mathbf{3})$ arch angle; (b) average and standard deviation of all biometric variables used in the current study for each track

\section{Chronology}

Another objective of this project has been to specify the chronology of the tracks in order to contextualize the activities that took place in this sector of the cave, the deep zone over 1 kilometre from the current entrance of Palomera.

To study transit and use in this sector of the system in greater depth, since 2016 we have been conducting a project with the aim of surveying and dating the surroundings of the sector, including Sala and Galerías de las Huellas, on the third level of Ojo Guareña, and Galería del Cacique and its side passages, as well as Laberinto Otilio and Sala Negra, on the fourth level, i.e. lower than Huellas and the main level within the Ojo Guareña Cave system.

Sixteen organic samples were taken for radiocarbon dating. AMS dating of 15 samples was performed at BETA Analytic Inc., between 2017 and 2019. The Gif-1721 sample, dated at the ${ }^{14} \mathrm{C}$ Gif Radiocarbon Laboratory in 1974 , completes Table 17.3. 


\section{Results}

\section{Footprints and Trackways}

Although the study has not yet been completed, about 700 footprints have been identified and at least 8-9 entry trackways to GH I and about 10-11 exit trackways (Fig. 17.6). Many superimposed footprints follow an apparently chaotic pattern at the junction with a side passage. This may indicate that some people explored that passage, while the others waited in the main passage.

About 500 human footprints have been identified in GH II, as well as a minimum of 7 entry trackways and 11 exit trackways towards Sala de las Huellas. In addition, the new cartography shows that one of the visitors separated from the group to inspect one of the hidden corners of the gallery (Fig. 17.7).

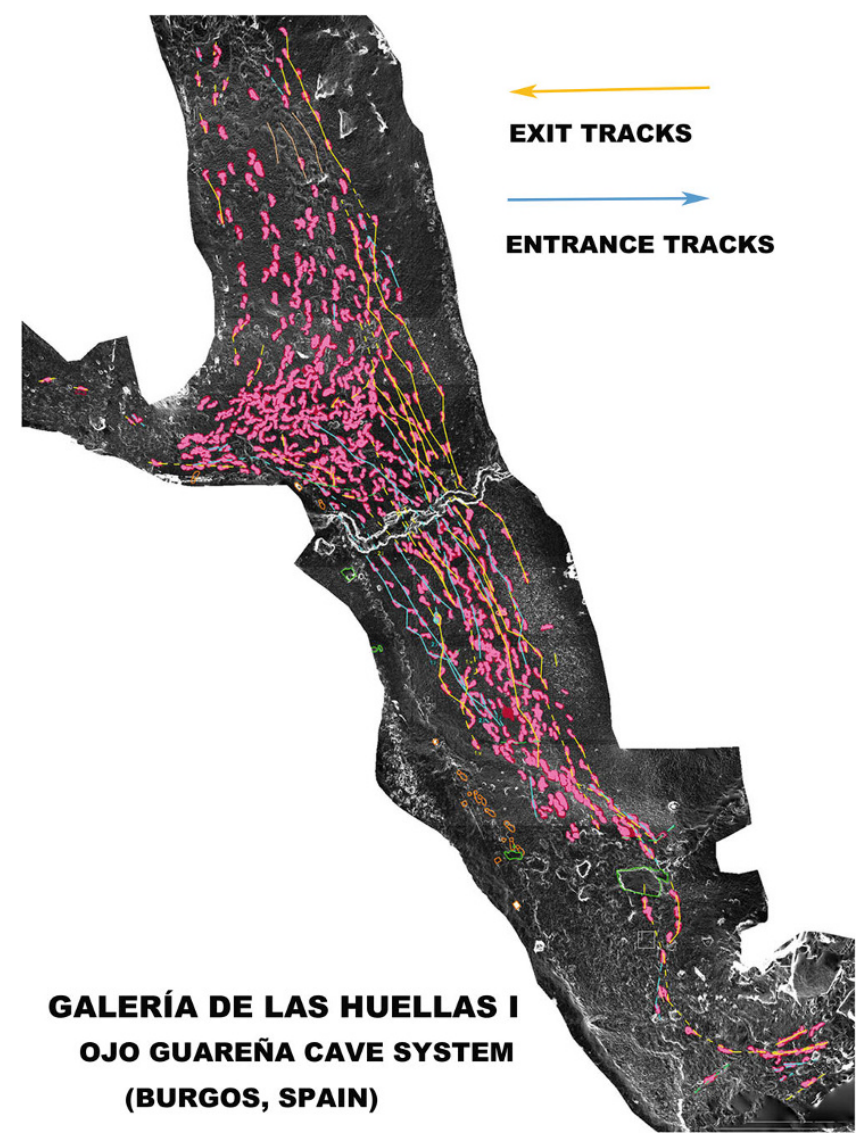

Fig. 17.6 Plan of the Galería de las Huellas I, from the scanner, with the identification of imprints and trackways 


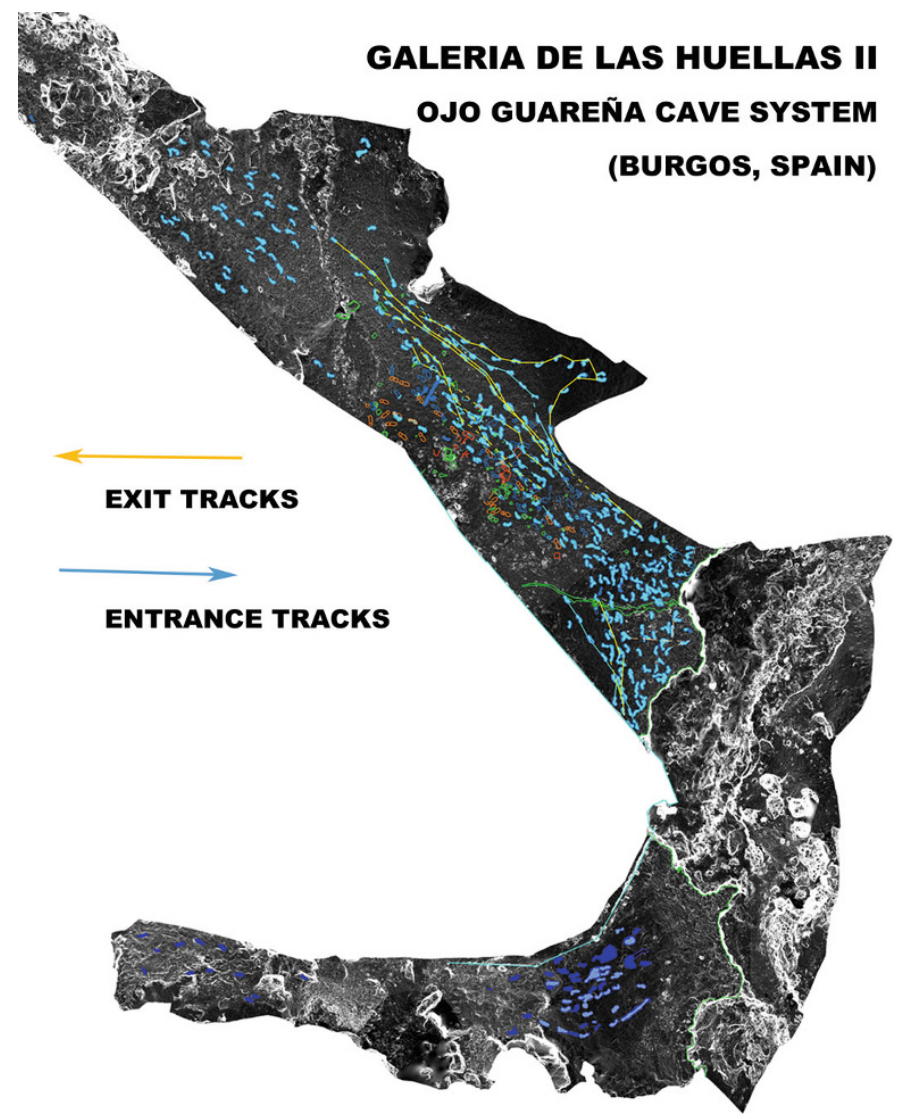

Fig. 17.7 Plan of the Galería de las Huellas II, from the scanner, with the identification of imprints and trackways

A preliminary study of $39 \mathrm{GH}$ I footprints will be described. They are integrated in seven trackways in Galería de las Huellas I: two in an entry direction (trackways 1 and 2) and the remaining five in the exit direction towards Sala de las Huellas (Fig. 17.8 and Table 17.1). All these footprints are located on the sides of the passage and correspond to 22 right feet and 17 left feet. They are in an excellent state of preservation, with the identification of complete footprints with clear anatomical features (toes, balls, heels, etc.) in the form of a low relief in the soft loam sediment.

The measurements of the maximum lengths and widths of the footprints are given in Table 17.1.

The sample of footprints is characterized by a certain uniformity in foot length, with measurements ranging between 250 and $290 \mathrm{~mm}$, resulting in average estimated heights of between 173 and $188 \mathrm{~cm}$ (Tables 17.1 and 17.2). This suggests that the footprints correspond to adult individuals, probably males. The foot width range shown in Table 17.2 varies from narrower traces, about $123 \mathrm{~mm}$ wide, to prints about 

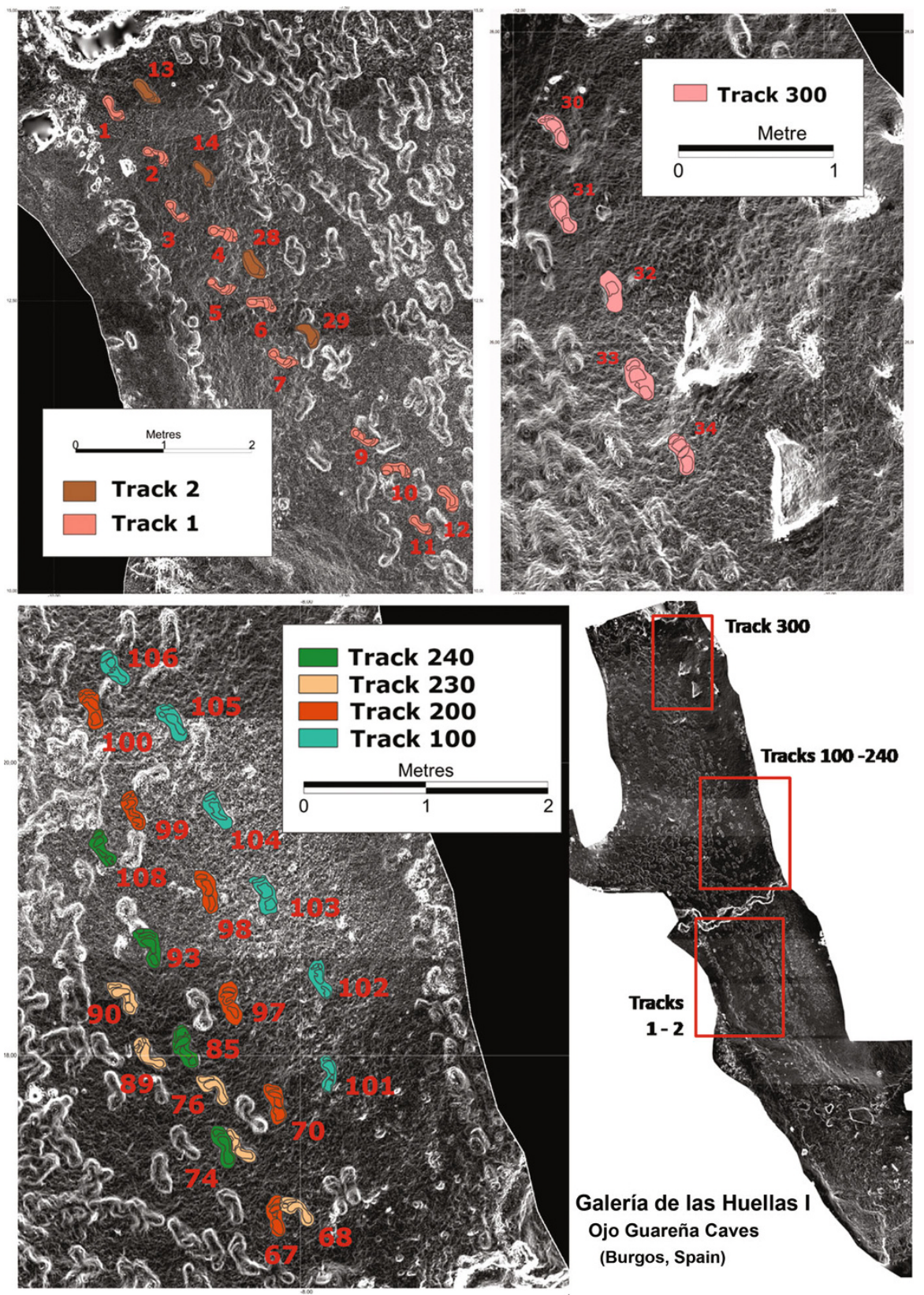

Fig. 17.8 Identification of the trackways and imprints analysed in this study. Galería de las Huellas I, Ojo Guareña Cave system 
Table 17.1 Main measurements of the 39 footprints (grouped in 7 trackways) selected for this study, from Galería de las Huellas I (mm)

\begin{tabular}{|c|c|c|c|c|}
\hline ID_Foot & $\mathrm{L} / \mathrm{R}$ & FL & FW & FHW \\
\hline 1 & $\mathrm{R}$ & 251 & 112 & 79 \\
\hline 2 & $\mathrm{~L}$ & 247 & 129 & 84 \\
\hline 3 & $\mathrm{R}$ & 247 & 111 & 81 \\
\hline 4 & $\mathrm{~L}$ & 263 & 128 & 76 \\
\hline 5 & $\mathrm{R}$ & 259 & 118 & 88 \\
\hline 6 & $\mathrm{~L}$ & 256 & 134 & 76 \\
\hline 7 & $\mathrm{R}$ & 266 & 122 & 80 \\
\hline 9 & $\mathrm{R}$ & 247 & 106 & 77 \\
\hline 10 & $\mathrm{R}$ & 257 & 139 & 109 \\
\hline 11 & $\mathrm{R}$ & 226 & 121 & 84 \\
\hline 12 & $\mathrm{~L}$ & 255 & 138 & 11 \\
\hline 13 & $\mathrm{R}$ & 273 & 112 & 100 \\
\hline 14 & $\mathrm{~L}$ & 258 & 119 & 82 \\
\hline 28 & $\mathrm{R}$ & 272 & 155 & 113 \\
\hline 29 & $\mathrm{~L}$ & 245 & 147 & 72 \\
\hline 101 & $\mathrm{R}$ & 249 & 117 & 75 \\
\hline 102 & $\mathrm{~L}$ & 264 & 131 & 100 \\
\hline 103 & $\mathrm{R}$ & 258 & 134 & 123 \\
\hline 104 & $\mathrm{~L}$ & 272 & 129 & 92 \\
\hline 105 & $\mathrm{R}$ & 272 & 139 & 105 \\
\hline 106 & $\mathrm{~L}$ & 256 & 145 & 97 \\
\hline 67 & $\mathrm{~L}$ & 269 & 124 & 97 \\
\hline 70 & $\mathrm{R}$ & 274 & 126 & 104 \\
\hline 97 & $\mathrm{~L}$ & 267 & 148 & 118 \\
\hline 98 & $\mathrm{R}$ & 292 & 137 & 90 \\
\hline 99 & $\mathrm{~L}$ & 266 & 123 & 102 \\
\hline 100 & $\mathrm{R}$ & 271 & 143 & 106 \\
\hline 68 & $\mathrm{R}$ & 254 & 124 & 94 \\
\hline 76 & $\mathrm{R}$ & 271 & 143 & 82 \\
\hline 89 & $\mathrm{~L}$ & 259 & 136 & 88 \\
\hline 90 & $\mathrm{R}$ & 267 & 144 & 106 \\
\hline 74 & $\mathrm{R}$ & 288 & 132 & 120 \\
\hline 85 & $\mathrm{~L}$ & 290 & 150 & 108 \\
\hline 93 & $\mathrm{R}$ & 287 & 150 & 104 \\
\hline 108 & $\mathrm{~L}$ & 257 & 140 & 103 \\
\hline 30 & $\mathrm{R}$ & 249 & 116 & 91 \\
\hline 31 & $\mathrm{~L}$ & 264 & 125 & 108 \\
\hline 33 & $\mathrm{~L}$ & 281 & 156 & 86 \\
\hline 34 & $\mathrm{R}$ & 273 & 135 & 105 \\
\hline
\end{tabular}

$L / R$ left or right, $F L$ foot length, $F W$ foot width, $F H W$ foot heel width 


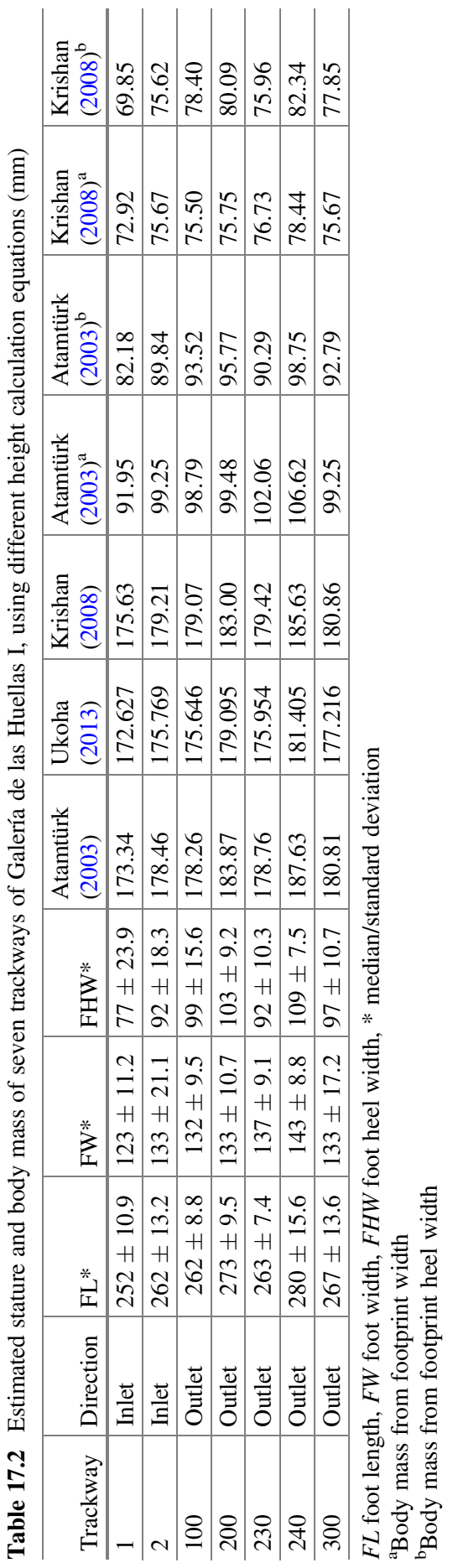


133, 137 and $144 \mathrm{~mm}$ wide (Tables 17.1 and 17.2). These values stress the presence of strong individuals.

Despite the uniformity in foot size among the trackways analysed, the AI and the AA reveal some morphological differences. The AA shows a tendency to flatness or pronation in all trackways $\left(\mathrm{AA} \leq 31^{\circ}\right)$, except in trackway 230, which corresponds to a normal range (Fig. 17.5b). Furthermore, the AI suggests a normal arch range for all trackways, except for trackway 230, which displays a slightly high arch, and for trackway 2 and trackway 300, which display a flat arch. These flat arches according to the AI are commonly a consequence of weight-bearing activities, so it may suggest that some individuals were carrying an additional weight.

The analysed footprints belong to seven trackways, which represent a minimum of five individuals according to the direction of the trackways (two entry trackways and five return trackways) (Fig. 17.8). The length and width measurements of trackways 2 and 100 are similar, which suggests that these may belong to the round-trip trackway of the same individual, whose estimated height is about $175-179 \mathrm{~cm}$. The weight calculations are more disparate, however. Depending on the chosen equations and markers, the weight could be either about 76-78 kg or 90-99 kg (Table 17.2).

\section{Chronology}

The chronology of the trackways has been determined in order to contextualize the activities that took place in this part of the cave, over 1 kilometre from the current entrance of Palomera Cave.

Delibrias et al. (1974: 53) published four radiocarbon dates from Ojo Guareña, and Sample Gif-1720 (OG2), from the footprint site, provided an age of $15,600 \pm 230 \mathrm{BP}$, in the Upper Palaeolithic. This sample, collected in 1970, was taken from the charred remains of a torch at the bottom of a pit that connects Laberinto Otilio (lower level) with Galerías de las Huellas (upper level). In 1999, a new date of charcoal on a footprint in Galería de las Huellas II was more recent, $3820 \pm 50 \mathrm{BP}$ (pers. comm. Juan Luis Arsuaga), which suggests that both Palaeolithic hunter-gatherers and Chalcolithic farmers transited this sector of the cave (Ortega et al. 2013: 182).

The new survey has identified a significant amount of evidence of visits, totalling 60 records: 6 remains in Sala Negra, 23 in Laberinto Otilio and side passages of Galería del Cacique, 22 in Sala de las Huellas and another 9 in Galerías de las Huellas I and II, different from the footprints (Fig. 17.9).

In all these passages we have documented scattered remains of charred wood as well as small concentrations of charcoal and charred wood marks on the walls and boulders, to mark the rock or rekindle the torches. Several panels of bear claw scratches on the walls and abundant mustelid imprints have been documented at the beginning of Galería de las Huellas I and also in the initial section of Laberinto Otilio. 
SALA AND GALERIAS DE LAS HUELLAS - FOOTPRINTS SITES OJO GUAREÑA KARST COMPLEX (Burgos, Spain)
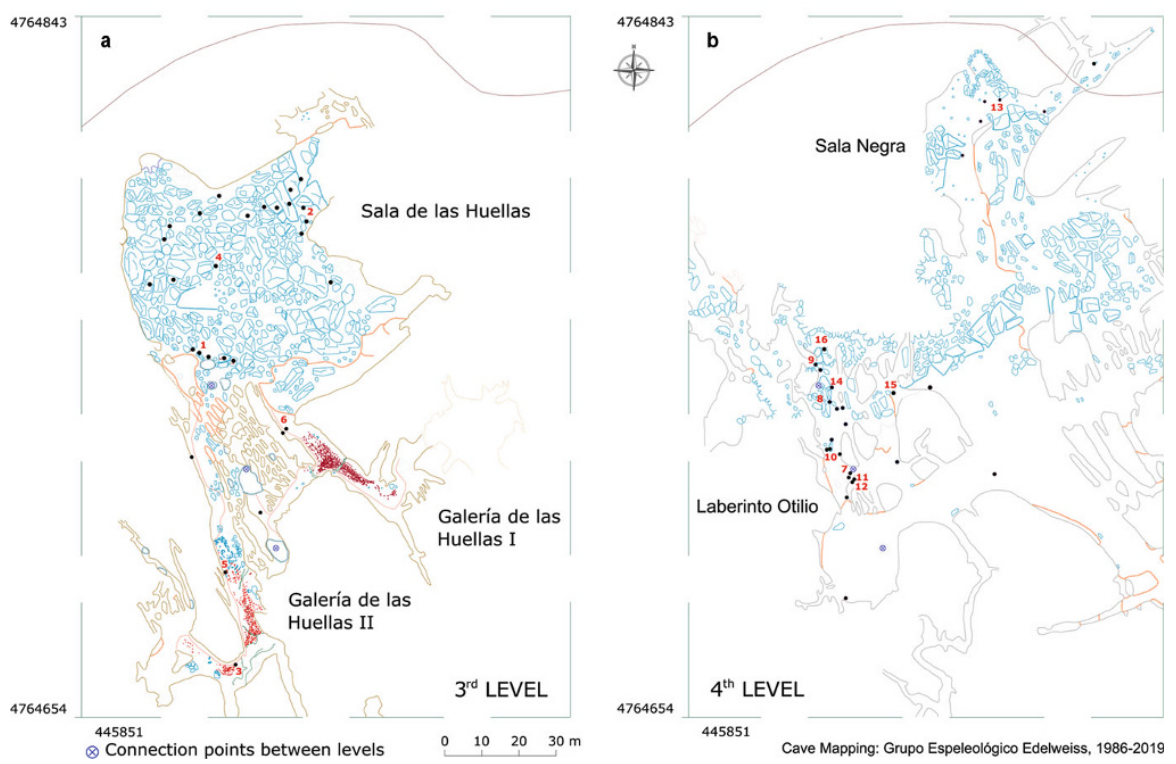

Fig. 17.9 Map of sector of the Sala and Galería de las Huellas site, separated in the different levels; (a) third level, Sala de las Huellas and Galería de las Huellas I-II; (b) fourth level, Laberinto Otilio and Sala Negra. The black points represent the archaeological evidences and the red numbers the dated samples, referred to in Table 17.3. (Modified from Grupo Espeleológico Edelweiss 1986; Ortega et al. 2014)

This survey has also documented the deterioration of the human footprints in Sala de las Huellas, in which only three areas with prints are preserved, all of them in the southern section of the great hall, on the irregular surface of the large inclined blocks covered with loam in which a few human footprints can be observed (Fig. 17.3a).

This study thus presents the results of 15 AMS radiocarbon determinations for samples from different pieces of charcoal and torches in the Otilio-Negra-Huellas sector (Figs. 17.2b-e, 17.3b and 17.9). They were selected from 55 points with charcoal identified in the archaeological surveying.

Table 17.3 reflects all the ages of the samples in the different sectors. The number refers to the identification of the sample on the maps in Fig. 17.9. The table has been divided into two groups, the upper one corresponds to the third level, with three dates from Sala de las Huellas, two from Galería de las Huellas II and one from Galería de las Huellas I. Additionally, it should be noted that we have been able to identify the 1999 sample in the field, which corresponds to sample 17.OG17.GH2. C2 (Fig. 17.9, number 3).

Regarding the fourth level of the karst, the survey of the northeast end of this sector could indicate a possible access from the San Bernabé blind valley (Figs. 17.1b, c and 17.2a), and one sample of the five identified in the blockage in 
Sala Negra has been dated (Fig. 17.9b, number 13). Eight samples from Laberinto Otilio have been dated, to add to Sample GIF-1721 OG2 published in Delibrias et al. (1974: 33) (Fig. 17.9b, numbers 7-12 and 14-16).

The distribution map and chronological table of the remains (Fig. 17.9 and Table 17.3) reveal the wide chronological range from the Upper Palaeolithic to the Chalcolithic in the Laberinto Otilio-Sala Negra sector and the concentration of dates in the third level.

The Palaeolithic sample (GIF-1721 OG2) was collected by members of the Grupo Espeleológico Edelweiss at the base of the pit that separates the two Galerías de las Huellas and connects with Laberinto Otilio (Figs. 17.2b and 17.9b, number 7). The new dates from this section of the maze are concentrated in the Late Mesolithic and Initial Neolithic (Fig. 17.9b and Table 17.3). A third period corresponds to the Chalcolithic, with two dates from the upper part of Laberinto Otilio, in areas with difficult access to Sala de las Huellas.

The spatial layout of archaeological evidence in Sala de las Huellas displays a clear perimeter distribution towards Galerías de las Huellas II and I. This southern part of the hall is next to a connection between boulders with the lower Otilio maze, and several charcoal fragments are observed in both levels. The charcoal identified as number 1 from Sala de las Huellas was dated to $4080 \pm 30 \mathrm{BP}$, and the charcoal from the upper part of Laberinto Otilio, number 16, was dated to $3850 \pm 30 \mathrm{BP}$ (Fig. 17.9 and Table 17.3).

In turn, the six samples from the Huellas Sector in the third level have ages between those two dates (Fig. 17.9a and Table 17.3). This suggests that the Huellas sector was explored in approximately 4300 calBP.

In contrast, visits in the immediately lower Otilio Sector took place in a wide chronological range from the Upper Palaeolithic to the Chalcolithic.

Table 17.3 Summary of the human footprint site ${ }^{14} \mathrm{C}$ data from charcoal, all unpublished and AMS except Gif-1721 (Delibrias et al. 1974)

\begin{tabular}{|c|c|c|c|c|c|c|c|}
\hline No & Site & Lab-no & Sample & ${ }^{14} \mathrm{C} \mathrm{BP}$ & calBP* & \begin{tabular}{|l} 
calBP* \\
$(\mathrm{m})$
\end{tabular} & Period \\
\hline \multirow[t]{3}{*}{1} & \multirow[t]{3}{*}{$\begin{array}{l}\text { SH (floor, } \\
\text { under block }\end{array}$} & \multirow[t]{3}{*}{$\begin{array}{l}\text { Beta- } \\
518405\end{array}$} & \multirow[t]{3}{*}{ 141.OG18.SH14 } & \multirow[t]{3}{*}{$4080 \pm 30$} & $\begin{array}{l}4648-4514 \\
(68 \%)\end{array}$ & \multirow[t]{3}{*}{4606} & \multirow[t]{3}{*}{$\mathrm{CH}$} \\
\hline & & & & & $\begin{array}{l}4806-4760 \\
(15.8 \%)\end{array}$ & & \\
\hline & & & & & $\begin{array}{l}4481-4445 \\
(7.9 \%)\end{array}$ & & \\
\hline 2 & SH (floor) & $\begin{array}{l}\text { Beta- } \\
518404\end{array}$ & 124.OG18.SH3.2 & $3910 \pm 30$ & $\begin{array}{l}4422-4248 \\
(95.4 \%)\end{array}$ & 4335 & $\mathrm{CH}$ \\
\hline \multirow[t]{2}{*}{3} & \multirow[t]{2}{*}{ GH-II (floor) } & \multirow[t]{2}{*}{$\begin{array}{l}\text { Beta- } \\
463838\end{array}$} & \multirow[t]{2}{*}{ 6.GH1 } & \multirow[t]{2}{*}{$3870 \pm 30$} & $\begin{array}{l}4414-4227 \\
(89.7 \%)\end{array}$ & \multirow[t]{2}{*}{4314} & \multirow[t]{2}{*}{$\mathrm{CH}$} \\
\hline & & & & & $\begin{array}{l}4200-4178 \\
(4.3 \%)\end{array}$ & & \\
\hline \multirow[t]{2}{*}{4} & \multirow[t]{2}{*}{ SH (floor) } & \multirow[t]{2}{*}{$\begin{array}{l}\text { Beta- } \\
518406\end{array}$} & \multirow[t]{2}{*}{ 144.OG18.SH21 } & \multirow[t]{2}{*}{$3860 \pm 30$} & $\begin{array}{l}4410-4225 \\
(84.0 \%)\end{array}$ & \multirow[t]{2}{*}{4301} & \multirow[t]{2}{*}{$\mathrm{CH}$} \\
\hline & & & & & $\begin{array}{l}4203-4158 \\
(11.4 \%)\end{array}$ & & \\
\hline
\end{tabular}


Table 17.3 (continued)

\begin{tabular}{|c|c|c|c|c|c|c|c|}
\hline No & Site & Lab-no & Sample & ${ }^{14} \mathrm{C}$ BP & calBP* & $\begin{array}{l}\text { calBP* } \\
(\mathrm{m})\end{array}$ & Period \\
\hline \multirow[t]{2}{*}{5} & \multirow[t]{2}{*}{ GH-II (floor) } & \multirow[t]{2}{*}{$\begin{array}{l}\text { Beta- } \\
473662\end{array}$} & \multirow[t]{2}{*}{ 17.OG17.GH2.C2 } & \multirow[t]{2}{*}{$3820 \pm 30$} & $\begin{array}{l}4299-4142 \\
(84.9 \%)\end{array}$ & \multirow[t]{2}{*}{4214} & \multirow[t]{2}{*}{$\mathrm{CH}$} \\
\hline & & & & & $\begin{array}{l}4126-4093 \\
(5.3 \%)\end{array}$ & & \\
\hline \multirow[t]{2}{*}{6} & \multirow[t]{2}{*}{ GH-I (floor) } & \multirow[t]{2}{*}{$\begin{array}{l}\text { Beta- } \\
473661\end{array}$} & \multirow[t]{2}{*}{ 16.OG17.GH1.C4 } & \multirow[t]{2}{*}{$3780 \pm 30$} & $\begin{array}{l}4245-4081 \\
(82.9 \%)\end{array}$ & \multirow[t]{2}{*}{4159} & \multirow[t]{2}{*}{$\mathrm{CH}$} \\
\hline & & & & & $\begin{array}{l}4031-4009 \\
(2.5 \%)\end{array}$ & & \\
\hline 7 & $\begin{array}{l}\text { LO (shaft } \\
\text { area, connec- } \\
\text { tion with GH } \\
\text { I) }\end{array}$ & $\begin{array}{l}\text { Gif- } \\
1721\end{array}$ & GOG2 & $15,600 \pm 230$ & $\begin{array}{l}19,392- \\
18,446 \\
(95.4 \%)\end{array}$ & 18,919 & UP \\
\hline 8 & LO (floor) & $\begin{array}{l}\text { Beta- } \\
463837\end{array}$ & 5.LO1 & $6940 \pm 30$ & $\begin{array}{l}7839-7689 \\
(95.4 \%)\end{array}$ & 7764 & $\mathrm{ME}$ \\
\hline 9 & LO (hearth) & $\begin{array}{l}\text { Beta- } \\
473663\end{array}$ & 18.OG17.LO1 & $6920 \pm 30$ & $\begin{array}{l}7826-7680 \\
(95.4 \%)\end{array}$ & 7753 & $\mathrm{ME}$ \\
\hline 10 & $\begin{array}{l}\text { LO (floor, } \\
\text { close to } \\
\text { torch) }\end{array}$ & $\begin{array}{l}\text { Beta- } \\
498596\end{array}$ & 104.OG18.LO9 & $6840 \pm 30$ & $\begin{array}{l}7732-7610 \\
(95.4 \%)\end{array}$ & 7671 & ME \\
\hline 11 & $\begin{array}{l}\text { LO (wall, } \\
\text { shaft, con- } \\
\text { nection with } \\
\text { GH I) } \\
\end{array}$ & $\begin{array}{l}\text { Beta- } \\
463836\end{array}$ & 4.LO2 & $5800 \pm 30$ & $\begin{array}{l}6670-6503 \\
(95.4 \%)\end{array}$ & 6587 & $\mathrm{EN}$ \\
\hline 12 & $\begin{array}{l}\text { LO (wall, } \\
\text { shaft, con- } \\
\text { nection with } \\
\text { GH I) } \\
\end{array}$ & $\begin{array}{l}\text { Beta- } \\
473664\end{array}$ & 19.OG17.LO2 & $5780 \pm 30$ & $\begin{array}{l}6656-6499 \\
(95.4 \%)\end{array}$ & 6578 & EN \\
\hline 13 & SN (floor) & $\begin{array}{l}\text { Beta- } \\
518403\end{array}$ & 119.OG18.SN4 & $5760 \pm 30$ & $\begin{array}{l}\text { 6650-6484 } \\
(95.4 \%)\end{array}$ & 6567 & EN \\
\hline \multirow[t]{2}{*}{14} & \multirow[t]{2}{*}{ LO (torch) } & \multirow[t]{2}{*}{$\begin{array}{l}\text { Beta- } \\
498597\end{array}$} & \multirow[t]{2}{*}{ 105.OG18.LO15 } & \multirow[t]{2}{*}{$5410 \pm 30$} & $\begin{array}{l}6289-6181 \\
(94.0 \%)\end{array}$ & \multirow[t]{2}{*}{6234} & \multirow[t]{2}{*}{ EN } \\
\hline & & & & & $\begin{array}{l}6139-6129 \\
(1.4 \%)\end{array}$ & & \\
\hline \multirow[t]{2}{*}{15} & \multirow[t]{2}{*}{$\begin{array}{l}\text { LO (upper } \\
\text { level) }\end{array}$} & \multirow[t]{2}{*}{$\begin{array}{l}\text { Beta- } \\
518402\end{array}$} & \multirow[t]{2}{*}{ 145.OG18.LO20 } & \multirow[t]{2}{*}{$3860 \pm 30$} & $\begin{array}{l}4410-4225 \\
(84 \%)\end{array}$ & \multirow[t]{2}{*}{4301} & \multirow[t]{2}{*}{$\mathrm{CH}$} \\
\hline & & & & & $\begin{array}{l}4203-4158 \\
(11.4 \%)\end{array}$ & & \\
\hline \multirow[t]{2}{*}{16} & \multirow[t]{2}{*}{$\begin{array}{l}\text { LO (upper } \\
\text { level) }\end{array}$} & \multirow[t]{2}{*}{$\begin{array}{l}\text { Beta- } \\
498598\end{array}$} & \multirow[t]{2}{*}{ 106.OG18.LO19 } & \multirow[t]{2}{*}{$3850 \pm 30$} & $\begin{array}{l}4407-4218 \\
(75.7 \%)\end{array}$ & \multirow[t]{2}{*}{4286} & \multirow[t]{2}{*}{$\mathrm{CH}$} \\
\hline & & & & & $\begin{array}{l}4209-4156 \\
(19.7 \%)\end{array}$ & & \\
\hline
\end{tabular}

SH Sala de las Huellas, $G H$ Galería de las Huellas, $L O$ Laberinto Otilio, $S N$ Sala Negra, $C H$ Chalcolithic, UP Upper Palaeolithic, ME Mesolithic, EN Early Neolithic, * calibrated with OxCal 4.2 using Intcal 13 (Bronk Ramsey 2009), $m$ median 


\section{Discussion}

An increasing number of sites with prehistoric human footprints are becoming known (Aldhouse-Green et al. 1992; Bell and Neuman 1997, 1999; Ambert et al. 2000; Facorellis et al. 2001; Onac et al. 2005; Bennett et al. 2010; Bennett and Morse 2014b; Citton et al. 2017; Ashton et al. 2014; S. Webb et al. 2006b; D. Webb et al. 2014; Atamtürk et al. 2018; Roach et al. 2016). Recent research approaching this type of site through different disciplines is contributing new knowledge of interaction between humans, the land and the environment in painted caves as special places (Pastoors et al. 2015, 2017).

The Sala and Galería de las Huellas can be framed within those sites that provide information on the use and transit of the dark zone of caves, where the tracks of old paths are preserved, but whose specific relationship with the concept of the natural, social and cultural environment is unknown (Mlekuž 2012; Moyes 2012).

In the case of the tracks in Ojo Guareña, their singularity lies in the fact that they are a long way from the possible entrance point sand without a direct relationship with symbolic spaces (rock art, burials, etc.), although these exist in other parts of the cave system. The large number of traces is unique, with over 1200 footprints of a minimum of 6 individuals but probably of between 9 and 11, according to the trackways that have been counted.

The superimposition of the footprints, in opposite directions, is indicative of round-trips, which suggests a single inspection of these passages, during which some members approached the recesses of the walls or entered the side passage in GH I. These preliminary observations are visible in both of the Galerías de las Huellas passages.

It can therefore be proposed that the human footprints in the Sala and Galerías de las Huellas correspond to a single visit, possibly to explore this deep sector of the cave.

However, the human visits or tours that have been documented at different times in the Laberinto Otilio-Sala Negra sector are more difficult to comprehend. This sector is characterized by the absence of archaeological record and the isolation of the sector from places of symbolic activity. Nevertheless, this space was visited on at least four occasions in prehistory: the first about 19,000 calBP, the second moment around 7700 calBP, the third about 6500 calBP and the last time in relation with the exploration of the Huellas sector about 4300 calBP.

The results of this project show that the first significant explorations in Laberinto Otilio, a relatively comfortable maze in its initial section, took place in the Mesolithic and Early Neolithic, the times of which the first remains are preserved in Sala Negra. During more intense explorations in the Chalcolithic, the unstable final ramp of large boulders was first accessed in order to reach the upper level where their footprints have been preserved in the Sala and Galerías de las Huellas. The challenges involved in access to this sector, combined with the spaciousness of its passages and the chaotic boulders on the floor, do not facilitate an understanding 
of the specific activities that took place, although they must be linked with the exploration and knowledge of the underground world.

The characteristics of this site mean that it cannot be compared with most human footprint sites, which are generally linked with the zones of habitats, or sacred or rock art sites, both in the open air and in caves (Bennett and Morse 2014b; Ashton et al. 2014; Westaway et al. 2013; Atamtürk et al. 2018). Ciur-Izbuc Cave, Romania (D. Webb et al. 2014); Bàsura Cave, Italy (Citton et al. 2017); Aldène Cave (Ambert et al. 2000); and Foissac Cave, France (García and Duday 1983), dated in the Middle Palaeolithic, Upper Palaeolithic, Mesolithic and Chalcolithic, respectively, are not associated with symbolic elements. Foissac Cave was quarried for clay in the Chalcolithic. The deep zone of Mammoth Cave (United States) was also used for mining activities (Kennedy and Watson 1997; Willey et al. 2009). However, the prehistoric traces in Jaguar Cave (Tennessee, USA) are more interesting for our case study. Watson et al. (2005) documented a single visit by a group of nine individuals about 4500 BP. The cave was never used for any specific purpose, so the tracks represent an isolated event.

The footprint site in Sala and Galerías de las Huellas similarly represents a single event, a simple exploration, but its surroundings, Laberinto Otilio, Sala Negra and Galería del Cacique, were explored earlier several times. They are in the eastern part of Palomera Cave, where different types of evidence and human activities have been identified over a distance of more than a kilometre in length. They show that during prehistory, the inhabitants of this karst transited and explored the cave until they met the sediment plug in the San Bernabé cirque, leaving marks in the underground landscape, small hearths, torches, stones or rock art, graves, etc.

This indicates that the exploration of the interior of this cave system was an activity that was carried out with certain normality. This exploration must have represented an initial contact of the underground world that they wanted to conquer and then select at a later time the different symbolic places that have contributed to the singularity of this site, which has been designated as Spanish Cultural Heritage since 1972 .

\section{Conclusion}

The human footprint site of Sala and Galerías de las Huellas is one of the most important sites in the Ojo Guareña Cave system, located about $1200 \mathrm{~m}$ from Palomera Cave. It is dated in about 4600-4200 calBP, a range that suggests a use of the dark area of the cave in the Chalcolithic, although intensive human traffic in the immediate environment (Laberinto Otilio-Sala Negra-Sala del Cacique) is documented during the Upper Palaeolithic, Mesolithic and Neolithic.

The analyses suggest that a group of between 8 and 10 adults explored several passages in the Dédalo Oeste sector of this large cave, leaving more than 1200 footprints in the soft sediment on the floor of Galería de las Huellas. The exceptionality of this incursion is due to the complexity of access. This survey of the route taken by the explorers and their trackways is improving our knowledge of the use of 
the underground world in prehistory. The analyses of the numerous evidences of transit in this big cave are helping us to understand the intensity of cave use in prehistory and especially the use of the dark zone as a symbolic and social landscape.

The research also proves the value of optical laser scanning and photogrammetry in the collection of data, analysis and preservation of the fragile footprints.

Acknowledgements We appreciate Andreas Pastoors and Tilman Lenssen-Erz's invitation to participate in the International Conference on Prehistoric Human Tracks (Colonia 2017) and to write this article. We thank Peter Smith for the comments and corrections on the paper, and for the revision of the translation of the text, which have significantly improved the manuscript.

The research was done with the permission of the DG Cultural Heritage of the Regional Government of Castilla y León, which also funded the Carbon Dating of the Cultural Heritage of Ojo Guareña Cave system (2017-2020).

The authors also wish to thank the Team of the Grupo Espeleológico Edelweiss for their constant scientific and technical support, especially with the documentation of photographs and maps of the Ojo Guareña caves. We thank the Laboratory of Digital Mapping and 3D Analysis of CENIEH for the technical support in relation to the scanner work. We are also grateful to the staff of the Fundación Atapuerca for their logistical help in the project.

\section{References}

Aldhouse-Green, S. H. R., Whittle, A. W. R., Allen, J. R. L., Caseldine, A. E., Culver, S. J., Day, M. H., Lundquist, J., \& Upton, D. (1992). Prehistoric human footprints from the Severn Estuary at Uskmouth and Magor Pill, Gwent, Wales. Archaeologia Cambrensis, 149, 14-55.

Ambert, P., Colomer, A., \& Galant, P. (2000). Datations mésolithiques des empreintes humaines de l'étage Cathala de la grotte d'Aldène (Cesseras, Hérault). Earth and Planetary Science, 331(1), 67-74. https://doi.org/10.1016/S1251-8050(00)01380-X.

Ashton, N., Lewis, S. G., De Groote, I., Duffy, S. M., Bates, M., Bates, R., Hoare, P., Lewis, M., Parfitt, S. A., Peglar, S., Williams, C., \& Stringer, C. (2014). Hominin footprints from Early Pleistocene deposits at Happisburgh, UK. Plos ONE, 9(2), e88329. https://doi.org/10.1371/ journal.pone.0088329.

Atamtürk, D. (2003). Ayak ve ayak ölçülerinden boy uzunluğu ve vücut ă̆ırlı̆̆ının tahmini üzerine adli antropolojik bir araştırma. Department of Anthropology, Institute of Social Sciences, Hacettepe University, Ankara: Unpublished MA Thesis.

Atamtürk, D., \& Duyar, I. (2008). Age-related factors in the relationship between foot measurements and living stature and body weight. Journal of Forensic Sciences, 53(6), 1296-1300. https://doi.org/10.1111/j.1556-4029.2008.00856.x.

Atamtürk, D., Özbal, R., Gerritsen, F., \& Duyar, I. (2018). Analysis and interpretation of Neolithic Period footprints from Barcin Höyük, Turkey. Mediterranean Archaeology and Archaeometry, 18(1), 163-174.

Bell, M., \& Neuman, H. (1997). Prehistoric intertidal archaeology and environments in the Servern Estuary, Wales. World Archaeology, 29(1), 95-113.

Bell, M., \& Neuman, H. (1999). Intertidal survey, assessment and excavation of a Bronze Age site at Redwick, Gwent. Archaeology in the Severn Estuary, 10, 25-37.

Benito-Calvo, A., Ortega, A. I., Ruiz, F., Karampaglidis, T., Campaña, I., \& Martín, M. A. (2013). Aplica-ción de escáneres láser 3D y técnicas GIS para la reconstrucción y análisis de yacimientos arqueológicos: las Galerías de las Huellas (Complejo Kárstico de Ojo Guareña, Burgos). In R. Baena, J. J. Fernández, \& I. Guerrero (Eds.), El Cuaternario Ibérico: Investigación en el s. XXI. VIII Reunión de Cuaternario Ibérico (pp. 219-221). La Rinconada-Sevilla: AEQUA. 
Bennett, M. R., Falkingham, P., Morse, S. A., Bates, K., \& Crompton, R. H. (2013). Preserving the impossible: Conservation of soft-sediment Hominin footprint sites and strategies for threedimensional digital data capture. PLoS One, 8(4), e60755. https://doi.org/10.1371/journal. pone.0060755.

Bennett, M. R., \& Morse, S. A. (2014a). World review of human track sites. In M. R. Bennett \& S. A. Morse (Eds.), Human footprints: Fossilised locomotion? (pp. 47-79). Dordrecht: Springer.

Bennett, M. R., \& Morse, S. A. (2014b). Prehistoric human footprint sites. In C. Smith (Ed.), Encyclopedia of global archaeology (pp. 6123-6128). New York: Springer.

Bennett, M. R., Gonzalez, S., Huddart, D., Kirby, J., \& Toole, E. (2010). Probable Neolithic footprints preserved in inter-tidal peat at Kenfig, South Wales (UK). Proceedings of the Geologists' Association, 121, 66-76.

Bronk Ramsey, C. (2009). Bayesian analysis of radiocarbon dates. Radiocarbon, 51(1), 337-360.

Cavanagh, P. R., \& Rodgers, M. M. (1987). The arch index: A useful measure from footprints. Journal of Biomechanics, 20(5), 547-551.

Citton, P., Romano, M., Salvador, I., \& Avanzini, N. (2017). Reviewing the upper Pleistocene human footprints from the 'Sala dei Misteri' in the Grotta della Bàsura (Toirano, northern Italy) cave: An integrated morphometric and morpho-classificatory approach. Quaternary Science Reviews, 169, 50-64. https://doi.org/10.1016/j.quascirev.2017.05.016.

Del Olmo, P., Ramírez, J., Aguilar, M. J., Portero, J. M., \& Olivé, A. (1978). Mapa Geológico de España e. 1:50.000. Hoja 84 (19-06). Espinosa de los Monteros: Serie Magna.

Delibrias, G., Guillier, M., \& Labeyrie, J. (1974). Gif natural radiocarbon measurements VIII. Radiocarbon, 16, 15-94.

Facorellis, Y., Kyparissi-Apostolika, N., \& Maniatis, Y. (2001). The cave of Theopetra, Kalambaka: Radiocarbon evidence for 50,000 years of human presence. Radiocarbon, 43(NR 2B), 129-148.

Galaz, J. S., Lázaro, F., \& Martín, M. Á. (2000). Fotografías estereoscópicas en Ojo Guareña realizadas durante los días 20, 21 y 22 de abril de 2000 (Unpublished report, 8 pp. Grupo Espeleológico Edelweiss).

García, M. A., \& Duday, H. (1983). Grotte de Foissac (Aveyron). A propos d'une découverte récente ou de l'ichnologie comme mode d'approche des structures préhistoriques en grotte. Bulletin de la Société Préhistorique Francaise, 8(6), 184-187.

González-Martín, C., Pita-Fernández, S., Seoane-Pillado, T., López-Calviño, B., Pertega-Díaz, S., \& Gil-Guillén, V. (2017). Variability between Clarke's angle and Chippaux-Smirak index for the diagnosis of flat feet. Colombia Médica, 48(1), 25-31.

Grupo Espeleológico Edelweiss (Ed.). (1986). Kaite. Estudios de espeleologia burgalesa. Merindad de Sotoscueva Monografía sobre Ojo Guareña. Burgos: Diputación Provincial of Burgos.

Kennedy, M. C., \& Watson, P. J. (1997). The chronology of Early Agriculture and Intensive Mineral Mining in the Salts Cave and Mammoth Cave Region, "Mammoth Cave National Park", Kentucky. Journal of Cave and Karst Studies, 59, 5-9.

Krishan, K. (2008). Estimation of stature from footprint and foot outline dimensions in Gujjars of North India. Forensic Science International, 175, 93-101.

Lockley, M., Roberts, G., \& Kim, J. Y. (2008). In the footprints of our ancestors: An overview of the hominid track record. Ichnos, 15(3), 106-125.

Martín, M. Á. (1986). Karst de Ojo Guareña: descripción morfológica. "Unidad Principal”. Sec-tor Dédalo Oeste. In Grupo Espeleológico Edelweiss (Ed.), Monografía sobre Ojo Guareña (pp. 137-160) (pp. 4-5). Kaite: Grupo Espeleológico Edelweiss.

Mlekuž, D. (2012). Notes from the underground: Caves and people in the Mesolithic and Neolithic Karst. In K. Bergsvik \& R. Skeates (Eds.), Caves in context: The cultural significance of caves and rockshelters in Europe (pp. 199-211). Oxford: Oxbow Books.

Moyes, H. (Ed.). (2012). Sacred darkness: A global perspective on the ritual use of caves. Boulder: University Press of Colorado.

Onac, B. P., Viehmann, I., Lundberg, J., Lauritzen, S. E., Stringer, C., \& Popita, V. (2005). U-Th ages constraining the Neanderthal footprint at Vârtop Cave, Romania. Quaternary Science Reviews, 24, 1151-1157. 
Ortega, A. I., \& Martín, M. A. (1986). La Arqueología del Karst de Ojo Guareña. In Grupo Espeleológico Edelweiss (Ed.), Monografía sobre Ojo Guareña (pp. 331-389) (pp. 4-5). Kaite: Grupo Espeleológico Edelweiss.

Ortega, A. I., \& Martín, M. Á. (2019). Investigaciones en torno a las Galerías de las Huellas de Ojo Guareña (Merindad de Sotoscueva, Burgos) tras 50 años de su descubrimiento. Cubía, 23, $22-31$.

Ortega, A. I., Martín, M. A., \& Grupo Espeleológico Edelweiss. (2013). Cuevas de Ojo Guareña. Una visión de la mano del Grupo Espeleológico Edelweiss. Burgos: Diputación Provincial de Burgos.

Ortega, A. I., Ruiz, F., Benito-Calvo, A., Martín, M. Á., Karampaglidis, T., \& Campaña, I. (2014). Es-caneado en 3D de las Galerías de las Huellas (Ojo Guareña, Merindad de Sotoscueva, Bur-gos). Cubía, 18, 38-47.

Osaba, B. (1969). Novedades arqueológicas y artísticas de Burgos. Boletín de la Institución Fernán González, 173, 300-312.

Pastoors, A., Lenssen-Erz, T., Ciqae, T., Kxunta, U., Rieke-Zapp, Thao, T., Bégouën, R., Biesele, M., \& Clottes, J. (2015). Tracking in caves: Experience based Reading of Pleistocene human footprints in French caves. Cambridge Archaeological Journal, 25(3), 551-564. https://doi.org/ 10.1017/S0959774315000050.

Pastoors, A., Lenssen-Erz, T., Breuckmann, B., Ciqae, T., Kxunta, U., Rieke-Zapp, D., \& Thao, T. (2017). Experience based Reading of Pleistocene human footprints in Pech-Merle. Quaternary International, 430, 155-162.

Riley, S. J., De Gloria, S. D., \& Elliot, S. D. (1999). A terrain ruggedness index that quantifies topographic heterogeneity. International Journal of Science, 5, 23-27.

Roach, N. T., Hatala, K. G., Ostrofsky, K. R., Villmoare, B., Reeves, J. S., Du, A., Braun, D. R., Harris, J. W. K., Behrensmeyer, A. K., \& Richmond, B. G. (2016). Pleistocene footprints show intensive use of lake margin habitats by Homo erectus groups. Scientific Reports, 6, 26374. https://doi.org/10.1038/srep26374.

Robbins, L. M. (1986). Estimating height and weight from size of footprints. Journal of Forensic Sciences, 31(1), 143-152.

Rubio, E. (2001). El descubrimiento de las huellas prehistóricas. Ojo Guareña. Cubía, 3, 34-35.

Ukoha, U., Egwu, O., Ezeani, M., Anyabolu, A., Ejimofor, O., Nzeako, H., \& Umeasalugo, K. (2013). Estimation of stature using footprints in an adult student population in Nigeria. International Journal Biomedical and Advance Research, 4(11), 827-822. https://doi.org/10. 7439/ijbas.

Uribarri, J. L. (1969). Las pinturas rupestres en Ojo Guareña, Burgos. In Verband der Deutschen Höhlen- und Karstforscher (Ed.), V. Int. Kongress für Speläologie Sttugart (pp. H9/1-H9/8). München: Verband der Deutschen Höhlen- und Karstforscher.

Watson, P. J., Kennedy, M. C., Willey, P., Robbins, L. M., \& Wilson, R. C. (2005). Prehistoric Foot-prints in Jaguar Cave, Tennessee. Journal of Field Archaeology, 30(1), 25-43. https://doi. org/10.1179/009346905791072440.

Webb, D., Bernardo, D. V., \& Hermenegildo, T. (2006a). Evaluating and improving footprint measurement for clinical and scientific testing. L'Anthropologie, 44, 269-279.

Webb, S., Matthew, L. C., \& Robins, R. (2006b). Pleistocene human footprints from the Willandra Lakes, southeastern Australia. Journal of Human Evolution, 50(4), 405-413. https://doi.org/10. 1016/j.jhevol.2005.10.002.

Webb, D., Robu, M., Moldovan, O., Consrtantin, S., Tomus, B., \& Neag, I. (2014). Ancient human footprints in Ciur-Izbuc Cave, Romania. American Journal of Physical Anthropology, 155, 128-135. https://doi.org/10.1002/ajpa.22561.

Westaway, M. C., Cupper, M. L., Johnston, H., \& Graham, I. (2013). The Willandra Fossil Trackway: Assessment of ground penetrating radar survey results and additional OSL dating at a unique Australian site. Australian Archaeology, 76(1), 84-89.

Willey, P., Watson, P. J., Crothers, G., \& Stolen, J. (2009). Holocene human footprints in North America. Ichnos, 16(1-2), 70-75. https://doi.org/10.1080/10420940802470839. 
Open Access This chapter is licensed under the terms of the Creative Commons Attribution 4.0 International License (http://creativecommons.org/licenses/by/4.0/), which permits use, sharing, adaptation, distribution and reproduction in any medium or format, as long as you give appropriate credit to the original author(s) and the source, provide a link to the Creative Commons license and indicate if changes were made.

The images or other third party material in this chapter are included in the chapter's Creative Commons license, unless indicated otherwise in a credit line to the material. If material is not included in the chapter's Creative Commons license and your intended use is not permitted by statutory regulation or exceeds the permitted use, you will need to obtain permission directly from the copyright holder. 